\title{
ON THE FORMATION OF SMALL MARGINAL LAKES ON THE JUNEAU ICEFIELD, SOUTH-EASTERN ALASKA, U.S.A.
}

\author{
By Matti SeppäLÄ \\ (Maantieteen Laitos, Turun Yliopisto, SF-20500 Turku 5o, Finland)
}

\begin{abstract}
This paper puts forward an explanation of the origin of small marginal lakes (superglacial or moat lakes) occasionally found on the edges of valley glaciers. The explanation departs from earlier theories. On the basis of observations made on the Juneau Icefield in south-eastern Alaska, I have come to the conclusion that the lake basins are primarily blow-outs formed as a result of wind erosion.
\end{abstract}

RÉsumé. Sur la formation des petits lacs marginaux sur le Juneau Icefield dans l'Alaska du Sud-Est, U.S.A. Cet article avance une explication de l'origine des petits lacs marginaux (lac surglaciaire ou lac de bordure) que l'on trouve parfois aux confins des glaciers de vallée. L'explication s'écarte des théories précédentes. Sur la base des observations faites au Juneau Icefield dans l'Alaska du sud-est, j'en suis venu à la conclusion que les bassins lacustres sont des formations d'origine éolienne résultant de l'érosion par le vent.

Zusammenfassung. Über die Bildung kleiner Randseen am Juneau-Eisfeld, Südost-Alaska, U.S.A. Die Arbeit enthält eine Erklärung der Entstehung kleiner Randseen (auf dem Eis oder zwischen Eis und Moräne ("Graben"-Seen)), wie sie gelegentlich an den Rändern von Talgletschern zu finden sind. Die Erklärung geht von früheren Theorien aus. Auf Grund von Beobachtungen am Juneau-Eisfeld im südöstlichen Alaska bin ich zu dem Schluss gekommen, dass die Seenbecken ursprünglich Auswehungsformen sind, die durch Winderosion entstanden.

\section{INTRODUCTION}

Small "moat lakes", sometimes empty, sometimes filled with water, are encountered on the edges of glacial firn areas of the Juneau Icefield in south-eastern Alaska. Earlier explanations for such minor marginal lakes are that they may develop alongside nunataks owing to reflected heat from the rock (e.g. Embleton and King, r968, p. 424).

In the summer of I97I I was afforded the opportunity of making observations on two marginal lakes on the Juneau Icefield: ( I) Lake Linda at the uppermost end of Lemon Creek Glacier (lat. $5^{\circ} 2 \mathrm{I}^{\prime}$ N., long. I $34^{\circ} 22^{\prime} \mathrm{W}$.; approximately I $200 \mathrm{~m}$ a.s.l.), and (2) Salla Lake at Icy Basin, a cirque on the margin of Taku Glacier about $27 \mathrm{~km}$ above its terminus (lat. $58^{\circ} 39^{\prime} \mathrm{N}$., long. I $34^{\circ} \mathrm{II}^{\prime} \mathrm{W}$.; approximately I $\mathrm{I} 50 \mathrm{~m}$ a.s.l.) (Fig. I) and, in addition, a number of other lakes by means of air photographic interpretation.

\section{EXPOSURE, FORM AND SIZE OF THE LAKES}

Lake Linda is situated between the Lemon Creek Glacier firn area and the moraine which forms the end wall of the glacier. Even on the rock-wall side, the oval-shaped lake basin is bordered for the most part by snow and ice (Fig. 2). It runs in a south-east to north-west direction, approximately that of the prevailing wind. The basin is about $300 \mathrm{~m}$ long, about $60 \mathrm{~m}$ broad at its widest point and about $25 \mathrm{~m}$ deep (Fig. 2). The slopes bordering the basin are steep; in some cases the slope was as much as $60^{\circ}$. In July $197 \mathrm{I}$, only an area measuring a little more than $100 \mathrm{~m}$ in length in the bottom of the basin was filled with water (Fig. 3). Because of the ice divide to the north of Lake Linda, the glacier flows slowly towards the lake basin even though the main flow of the glacier is in the opposite direction (Fig. 2).

Salla Lake lies between the rock bank which rises steeply towards the northern edge of Ice Basin and the glacier (Fig. 7). The cliff side of Salla Lake is bounded in the centre by ice and at either end by rock. The southern edge is completely ice bound. The lake is elongated in form and the direction of its longitudinal axis is $030^{\circ}-210^{\circ}$. The eastern end of the lake is broader than the western end. The lake basin is about $55^{\circ} \mathrm{m}$ long, has a maximum width of about $120 \mathrm{~m}$ and is about $12 \mathrm{~m}$ deep (Fig. 4). The slope bordering the lake is gentler than 


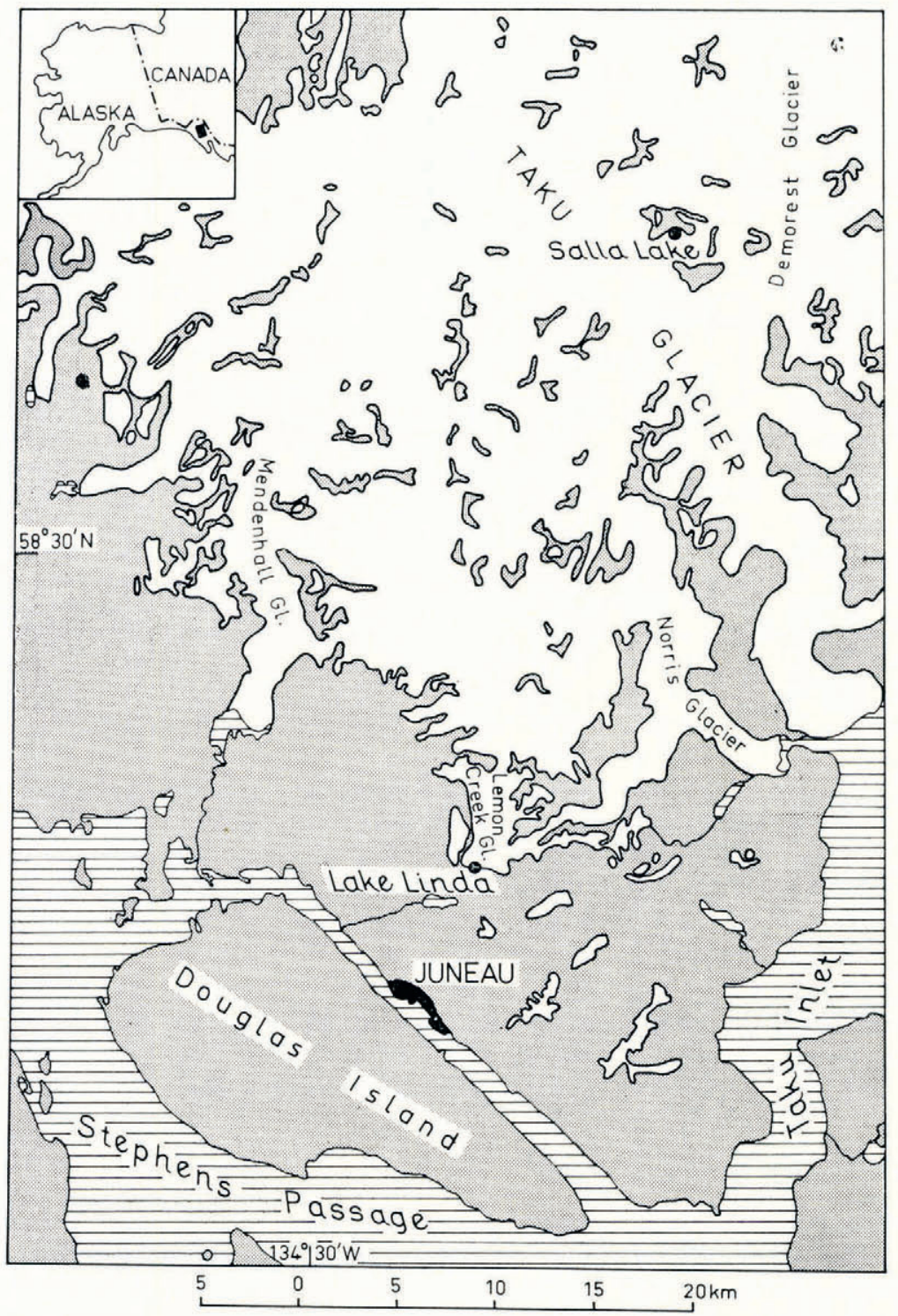

Fig. I. Map of the southern and central part of Juneau Icefield with location of the investigated small marginal lakes.

those of Lake Linda. The maximum inclination of the slopes is about $45^{\circ}$. The declivity of the surface of Icy Basin and crevasses in the ice indicate that the glacier flows from south, east and west towards the lake basin and tries to fill it (Fig. 5). In the bottom of the lake there can be found old blue ice composed of large crystals (5-10 cm in diameter). In July and August 1971, there was no longer any water in the lake.

\section{Formation AND DEVELOPMENT OF THE LAKES}

The formation of glaciers and the positions they occupy in mountainous tracts are largely dependent not only on the topography but also on the direction of the winds that bring snow 


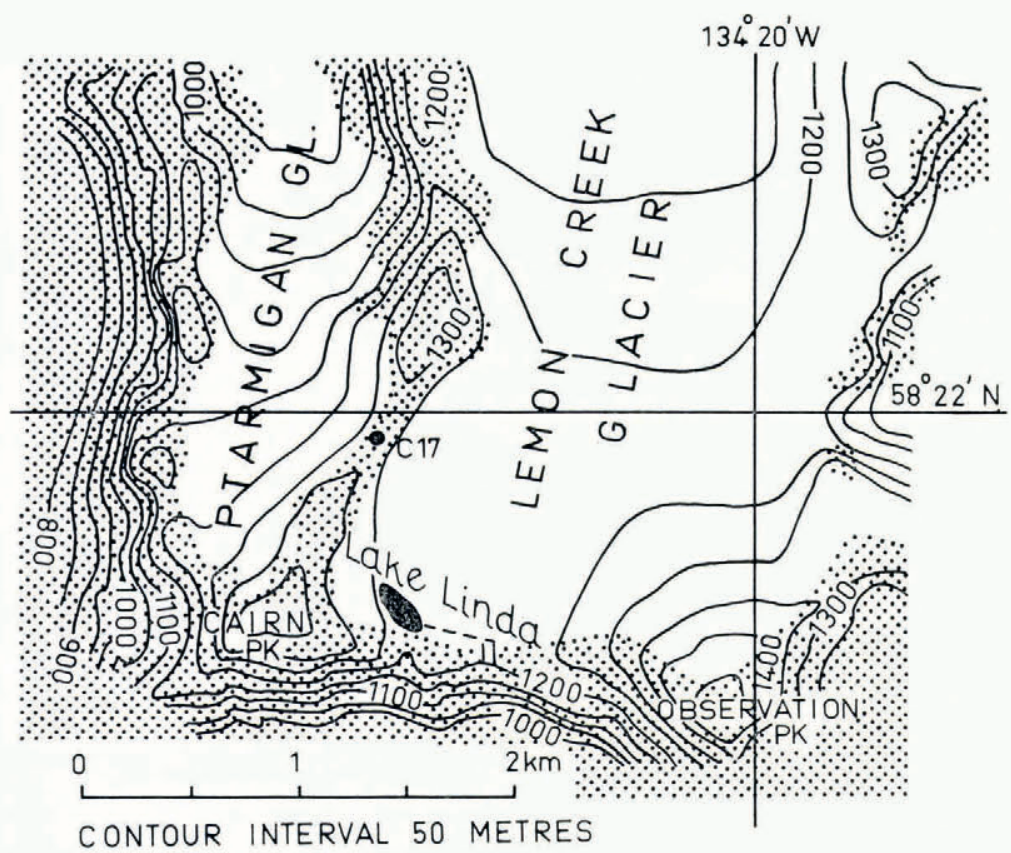

Fig. 2. Position of Lake Linda. Ice-free areas are shown by dots. The whole deflation basin is marked in black. CI7 is a permanent camp site. The dashed line is the subglacial outlet of the lake.

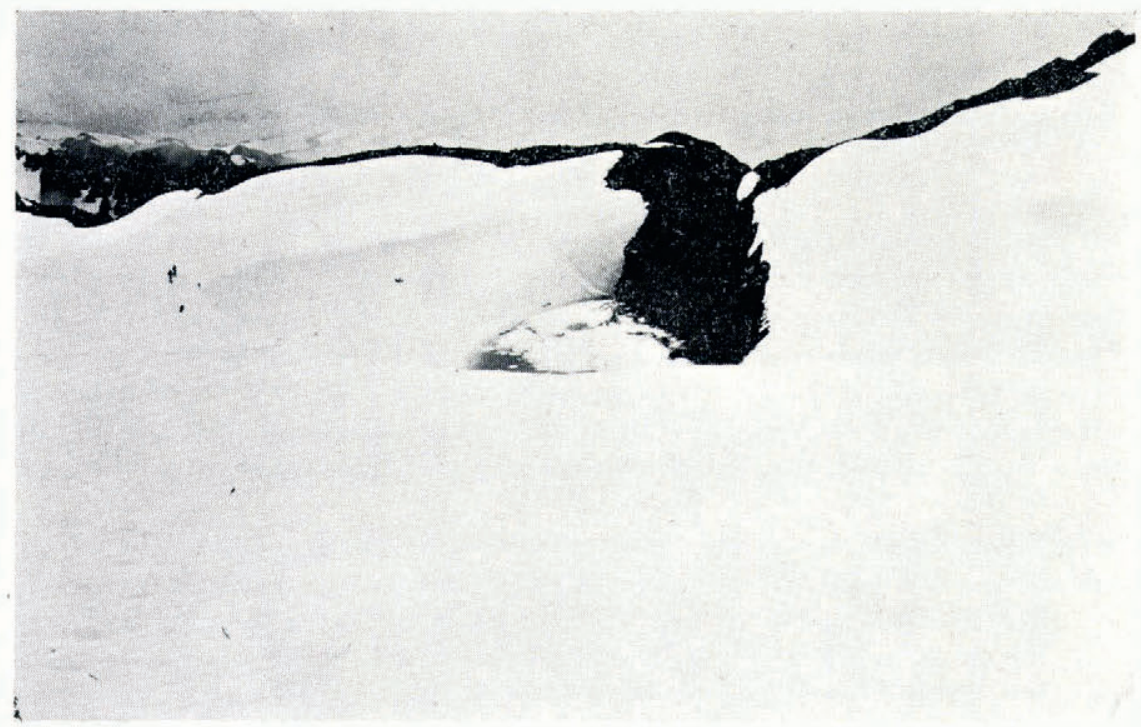

Fig. 3. General view of Lake Linda looking south-east. Photograph by the author, 12 July 1971 . 


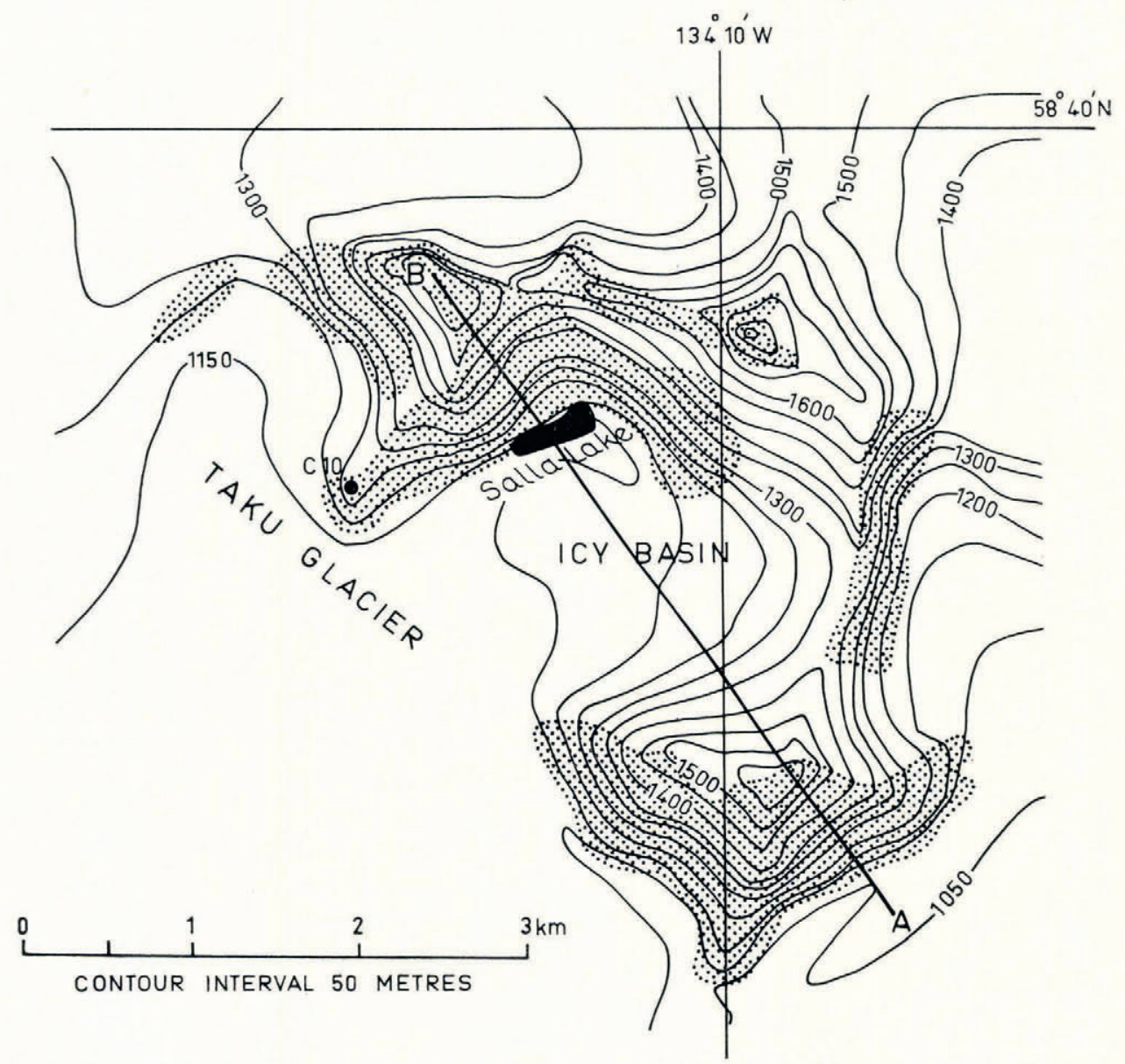

Fig. 4. Position of Salla Lake. Dotted areas are nunataks. Line $\mathrm{A}-\mathrm{B}$ indicates the profile line of Figure 6. Cro is the main camp site on the Funeau Icefield.

to the area. On the Juneau Icefield strong winds blow from the southern sector, principally from the south-east, and cause drifting (Miller, 1967, p. 208). This can be seen from the accumulation forms of the snow on the field and also from air photographs. Consequently, more snow tends to accumulate on the northern sides of the nunataks than on the southern sides, which face the wind. If the nunatak is in the form of a ridge following the direction of the wind, then a wind channel is formed on one or both sides. The snow does not pile up in such a channel to the same degree that it does elsewhere. This has happened in the case of Lake Linda.

If there is a steep wall of rock at right-angles to the direction of the wind, this causes eddying currents of wind to be formed which blow upwards, downwards or to the sides. They prevent in part the snow from piling up (Fig. 6). Such has been the case with Salla Lake. In the winter of $1970-7 \mathrm{I}$ the snow that had accumulated in the bottom of the lake was between $\mathrm{I}$ and $3 \mathrm{~m}$ thick judging from the melted snow that remained (Fig. 7). The thickness of the corresponding layer of snow on the even surface of nearby Taku Glacier was about $5 \mathrm{~m}$.

The lake basin continues to develop in such a way that melt water from the surface of the glacier and the slopes of the nunatak collects in the depression originally made by the wind. 


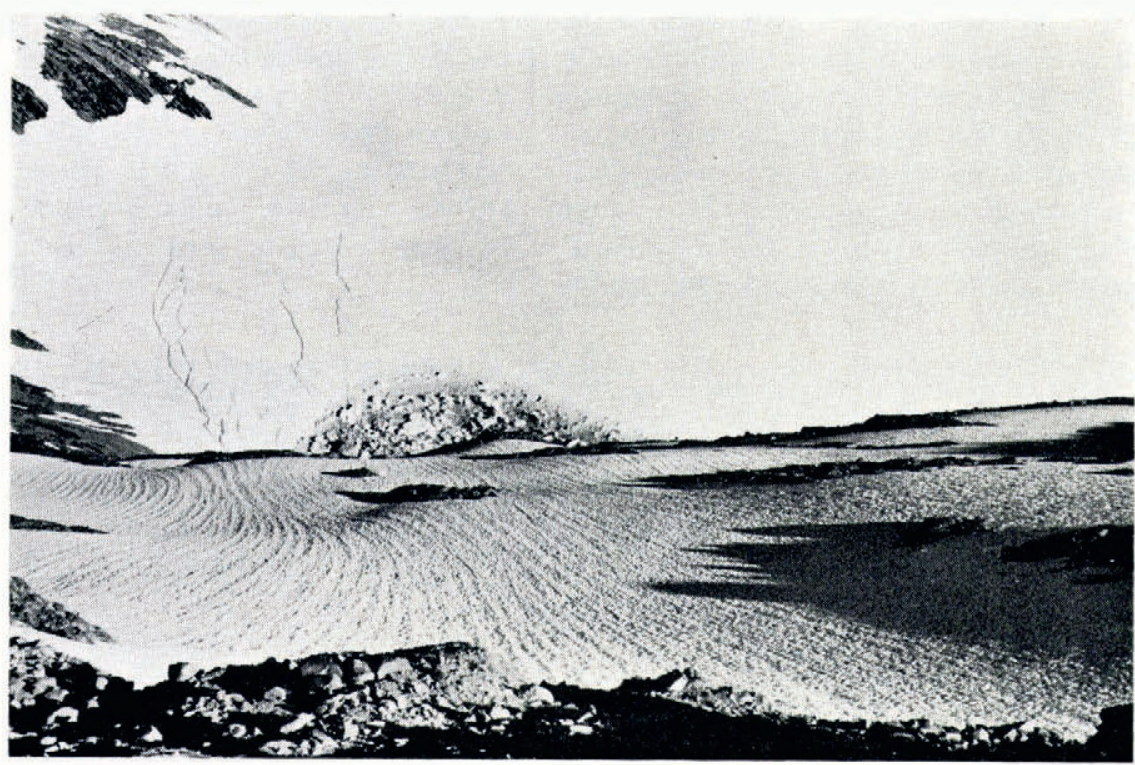

Fig. 5. View of Salla Lake looking down the slope of the nunatak towards Icy Basin. Crevasses surrounding the lake can be seen on the surface of the glacier. 31 July 1971 . (cf. Figs. 4 and 6.)

Such a pond enlarges its basin by melting the walls and floor by the heat of the water (cf. Maag, I969), which is carried to the periphery and the bottom by convection currents (cf. Sharp, 1947, p. 44). Melting lumps of ice and snow which have risen from the bottom or fallen from the sides of the lake float in the water.

Melt water flowing down from the slopes of the nunatak carries with it considerable quantities of sediment, which make the water muddy and at the same time dirty the floor of the lake and the ice and snow floating in the water. The lake may be emptied of water, sometimes catastrophically rapidly (Asher, I97I), as in the case of many ice-dammed lakes of other types (cf. Glen, I954; Aitkenhead, I960; Marcus, I96o; Lindsay, I966), when the ice floats to the surface and allows the water to drain out by way of a crevasse or tunnel in the bottom of the lake. A distinct dirty area is then left on the sides of the lake basin showing the extent of the water. Lumps of floating ice are deposited on the floor of the basin and, together with rocks which have rolled into the lake, form a chaotic topography (Fig. 7).

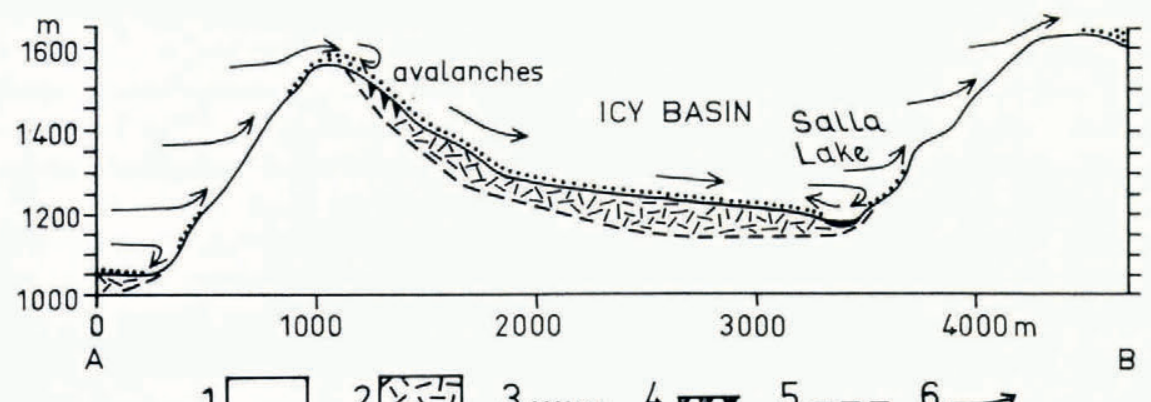

Fig. 6. Profile line A-B (see Fig. 4) showing the snow-drifting winds and snow accumulation (dots) on the Icy Basin glacier. Key to symbols: 1 . Bedrock; 2. Ice; 3. Snow deposits; 4. Crevasses; 5 . Approximate bottom of glacier; 6 . Wind direction. 
Because of the sediments, the albedo decreases and ablation increases to such a degree that nearly all of the snow which has piled up in the winter melts in the course of the summer and drains away as water through the bottom of the basin. The running water also helps to melt the ice in the bottom of the basin. There is a considerable difference in the albedo and ablation values for clean and dirty snow. This is clearly shown in the blocks of snow which have been floating in the water. These assume a mushroom-like shape of which the top consists of clean snow, while the foot is formed of the snow which has been under the water and has consequently melted much more quickly (Fig. 7).



Fig. 7. Mushroom-like blocks of snow at the bottom of the Salla Lake basin. Note the snow cover on the slope of the nunatak. 29 July 197 I.

The amount of heat reflected from the slopes of the nunatak is so small as not to be of any real significance as an ablation agent for the snow and ice lying in the lower parts of the lake basin. This is clearly seen from the position of Lake Linda (Figs. 2 and 3), situated as it is at the foot of a slope facing north. As far as Salla Lake is concerned, the slope does in fact face more or less south but in spite of that on the cliff side the lake is bounded by ice and snow in the centre. On the rock slope and the ice there was still white snow right down to the very edge of the water as late as the beginning of August I97 I (Figs. 4 and 7). Farther up the slope the snow had melted.

The following winter, snow piles up on the uneven surface of the bottom of the lake, but not in any great quantities. The snow accumulates for the most part in calm weather, even though drift snow blowing across the bed of the lake may collect to some degree because of the unevenness of the ground. However, for the most part the wind carries the snow to the edges of the basins. In any case the depression still exists the following spring; possibly its drainage tunnel has frozen solid in the course of the winter and so the basin can once more fill with water. The process then continues in the same way as during the preceding summer.

\section{Conclusions}

To confirm this theory of the origin of small marginal lakes, which is based principally on morphological and exposure factors, individual observations on the accumulation of snow, on ablation and microclimatic conditions in the lake basins should be carried out in the future. 
There are, in any case, a number of factors which provide evidence to the effect that too much importance has been hitherto attached to the influence exerted by heat reflected from nunataks.

\section{AGKNowledgements}

I am profoundly grateful to Professor Maynard M. Miller for giving me the chance of attending the 12th Summer Institute of Glaciological and Arctic Sciences, Juneau Icefield, Alaska, and also for many stimulating discussions as to the origin of moat lakes. To Mr Robert Asher I extend my thanks for his guidance in helping me to learn about Lake Linda. $\mathrm{Mr}$ Christopher Grapes kindly translated the manuscript into English.

This journey was made possible as a result of grants received from the National Science Foundation, U.S.A., the Leo and Regina Wainstein Foundation, Finland, and the National Research Council for Natural Sciences, Finland. To all of these institutions I wish to extend my best thanks.

MS. received ${ }_{15}$ March 1972 and in revised form ${ }_{13}$ November 1972

\section{REFERENGES}

Aitkenhead, N. 1960. Observations on the drainage of a glacier-dammed lake in Norway. Fournal of Glaciology, Vol. 3, No. 27, p. 607-09.

Asher, R. A. I971. Lake Linda drainage. Smithsonian Institution. Center for Short-lived Phenomena. Annual Report, I 970 , p. $85^{-89}$.

Embleton, C., and King, C. A. M. I968. Glacial and periglacial geomorphology. [London], Edward Arnold (Publishers) Ltd.

Glen, J. W. 1954. The stability of ice-dammed lakes and other water-filled holes in glaciers. Fournal of Glaciology, Vol. 2, No. 15, p. 316-18.

Lindsay, J. F. I 966 . Observations on the level of a self-draining lake on the Casement Glacier, Alaska. Fournal of Glaciology, Vol. 6, No. 45, p. 443-45.

Maag, H. U. I969. Ice dammed lakes and marginal glacial drainage on Axel Heiberg Island, Canadian Arctic Archipelago. Axel Heiberg Island Research Reports, McGill University, Montreal. Jacobsen-McGill Arctic Research Expedition $1959-1962$.

Marcus, M. G. I960. Periodic drainage of glacier-dammed Tulsequah Lake, British Columbia. Geographical Review, Vol. 5o, No. 1, p. 89-106.

Miller, M. M. 1967. Alaska's mighty rivers of ice. National Geographic Magazine, Vol. 131, No. 2, p. $194-217$.

Sharp, R. P. 1947. The Wolf Creek glaciers, St. Elias Range, Yukon Territory. Geographical Review, Vol. 37. No. I, p. $26-52$. 